九州大学学術情報リポジトリ

Kyushu University Institutional Repository

\title{
Alteration of yeast cell protein by denaturing agents
}

Kitamikado, Manabu

Laboratory of Chemistry of Fishery Product, Faculty of Agriculture, Kyusyu University

https://doi.org/10.5109/22681

出版情報：九州大学大学院農学研究院紀要. 11 (2)，pp. 155-164，1959-08. Kyushu University バージョン：

権利関係 : 
Journal of the Faculty of Agriculture, Kyūshū University, Vol. 11, No. 2 August 31, 1959

\title{
Alteration of yeast cell protein by denaturing agents
}

\author{
ManabU Kitamikado
}

In microbiology the treatments for inhibition of microbial growth have been carried out by using the denaturing agents such as acids, bases, organic solvents, salts of heavy metals, detergents, and other compounds as well as by heating, irradiation with ultraviolet rays or ultrasonic waves, and other physical means. It is commonly considered that the denaturing agents bring about the alteration of the microbial cell proteins and disturb the growth. By means of the determination of phosphorus or nitrogen flowing out of the cells, Hotchkiss ${ }^{2)}$ has demonstrated that certain detergents disrupted the surface structures of bacterial cells.

The author studied the effects of cations on the penetration of $\mathrm{Na}$ ion into the yeast cells and found that the cells took a larger amount of $\mathrm{Na}$ ion when certain heavy metal ions were present than when $\mathrm{Ba}, \mathrm{Ca}$, or $\mathrm{Mg}$ ion was present or when no other ions were

Table 1. Amounts of $\mathrm{Na}$ ion taken in yeast cell in the presence of various cations.

\begin{tabular}{l|c|c}
\hline Metallic salt & Conc. of metallic salt & $\mathrm{Na}$ ion in $\mathrm{cell}^{*}$ \\
\hline $\mathrm{BaCl}_{2}$ & $1 \times 10^{-1 \mathrm{M}}$ & $2.0 \mathrm{mg}$. \\
$\mathrm{CaCl}_{2}$ & $1 \times 10^{-1}$ & 2.0 \\
$\mathrm{MgCl}_{2}$ & $1 \times 10^{-1}$ & 2.0 \\
$\mathrm{CuCl}_{2}$ & $6 \times 10^{-2}$ & 3.0 \\
$\mathrm{HgCl}_{2}$ & $2 \times 10^{-3}$ & 3.6 \\
$\mathrm{AgNO}_{3}$ & $2 \times 10^{-3}$ & 3.5 \\
\hline Control & 0 & 2.0 \\
\hline
\end{tabular}

* Amount of $\mathrm{Na}$ ion in cell is expressed as $\mathrm{mg}$. of $\mathrm{NaCl} / 100 \mathrm{mg}$. of yeast cell. 
(Table 1). It was considered that this phenomenon resulted from the alteration of the yeast cells by heavy metals which act as denaturing agents of proteins. Therefore the changes of the amount of $\mathrm{Na}$ ion taken in cells, brought about not only by heavy metals but also by some other kinds of denaturing agents, were studied.

In microbiology it is a well-known process to distinguish living cells from dead cells by using certain dyes. After denaturation some proteins change their original capacity to combine with certain dyes. ${ }^{2-5)}$ Oster $^{(b)}$ has reported that fluoresceins (eosine, erythrosine and Bengal rose) hardly combined with intact tobacco mosaic virus or egg white, but that they combined with heated proteins and moreover modified their absorption spectra by the combination.

In this paper, therefore, the relationship between the adsorption of eosine yellowish by yeast cells and the denaturation of the cell proteins was also studied. In addition to the above experiments, the change of the activity of $\mathrm{SH}$ groups contained in yeast cells was studied, because the denaturation of protein is frequently accompanied by the increase of the activity of the groups.

\section{EXPERIMENTAL METHOD}

\section{1) Amount of $\mathrm{Na}$ ion taken in yeast cell}

After centrifuging the cultures of Saccharomyces sake (PeptoneHayduck medium, ${ }^{*} 30^{\circ} \mathrm{C}$., $40 \mathrm{hrs}$.), the cells were washed with distilled water 3 times and suspended in distilled water. Five ml. of cell suspension (including about $100 \mathrm{mg}$. wet cells), after the denaturing agent being added to it, was left for $5 \mathrm{~min}$. at room temperature $\left(15 \sim 16^{\circ} \mathrm{C}\right.$.). After centrifuging, the cells were washed with distilled water 2 times, and suspended again in $10 \mathrm{ml}$. of distilled water. Then $10 \mathrm{ml}$. of $2 \mathrm{M}$ $\mathrm{NaCl}$ solution was added to the suspension, and the latter was left for $10 \mathrm{~min}$. The suspension was filtered with No. 4 glass filter by using a strong sucker. The external moisture was removed from the yeast cells during the process of the filtration (the layer of the cells on the glass filter was less than $1 \mathrm{~mm}$. thick). Fifty $\mathrm{mg}$. of the treated cells was suspended in $20 \mathrm{ml}$. of distilled water, the $\mathrm{Na}$ ion content in this suspension was estimated by means of flame photometry at 589 $\mathrm{m} \mu$, and the amount of $\mathrm{Na}$ ion taken by yeast cells was calculated. In this case the cellular components scarcely interfere with this flame photometry (Table 2). The effect of heating was studied with the cell suspension which was heated in water bath at test temperature for 5 min., then cooled quickly down to room temperature.

\footnotetext{
* Peptone, $1 \%$; $\mathrm{MgSO}_{4} \cdot 7 \mathrm{H}_{2} \mathrm{O}, 0.3 \%$; $\mathrm{KH}_{2} \mathrm{PO}_{4}, 0.1 \%$; Glucose, $5 \%$
} 
Table 2. Effect of yeast cell components on the flame photometry of $\mathrm{Na}$ ion.

\begin{tabular}{|c|c|c|c|}
\hline No. & & Component of sample & $\begin{array}{l}\text { Conc. of } \\
\mathrm{Na} \text { ion }\end{array}$ \\
\hline 1 & $10 \mathrm{ml}$. of $3.4 \times 10^{-3} \mathrm{M}$ & $\mathrm{NaCl}+50 \mathrm{mg}$. washed cell & $101.8 \%$ \\
\hline 2 & " & $+50 \mathrm{mg}$. cell heated to $90^{\circ} \mathrm{C}$. & 97.5 \\
\hline 3 & " & $+50 \mathrm{mg}$. cell exposed to $\mathrm{M} / 10 \mathrm{KH}_{2} \mathrm{PO}_{4}{ }^{*}$ & 102.0 \\
\hline 4 & "I & $+50 \mathrm{mg}$. cell exposed to $2 \mathrm{M} \mathrm{H}_{2} \mathrm{SO}_{4}{ }^{*}$ & 102.2 \\
\hline 5 & " & $+50 \mathrm{mg}$. cell exposed to $3 \times 10^{-2} \mathrm{M} \mathrm{CaCl}_{2} *$ & 103.3 \\
\hline 6 & " & $+50 \mathrm{mg}$. cell exposed to $2 \times 10^{-3} \mathrm{M} \mathrm{HgCl}_{2}$ & 102.0 \\
\hline 7 & " & $+50 \mathrm{mg}$. cell exposed to $50 \%$ Ethanol & 104.5 \\
\hline 8 & $10 \mathrm{ml}$. of $3.4 \times 10^{-3} \mathrm{M}$ & $1 \mathrm{NaCl}$ (Control) & 100.0 \\
\hline
\end{tabular}

* It has been reported that a large amount of $\mathrm{P}, \mathrm{Ca}$ or strong acid interferes with the $\mathrm{Na}$ determination by flame photometric method.

Wallace, W. M., Holliday, M., Cushman, M. and Elkinton, J. R., 1951. J. Lab. and Clin. Med., 37, 621.

Parks, T. D., Johnson, H. O. and Lykken, L., 1948. Anal. Chem., 20, 822.

When the yeast cells were suspended in $1 \mathrm{M} \mathrm{NaCl}$ solution, the amount of $\mathrm{Na}$ ion taken in cells was $2 \mathrm{mg}$. expressed as $\mathrm{NaCl}$ per 100 mg. of the cells, and the percentage of the moisture of the cells was 46 , therefore the concentration of the $\mathrm{Na}$ ion in cell was about 75 per cent of that of the external environment.

\section{2) Adsorption of eosine by cells}

The denaturing agent was added to $5 \mathrm{ml}$. of washed cell suspension, and the suspension was left for $10 \mathrm{~min}$. The cells were centrifuged, washed with $\mathrm{M} / 50$ phosphate buffer solution ( $\mathrm{pH} 5.4) 2$ times, and suspended in $10 \mathrm{ml}$. of the same phosphate buffer solution. Ten $\mathrm{ml}$. of $2 \times 10^{-5} \mathrm{M}$ eosine yellowish solution was added to this suspension, and the optical density of the centrifuged supernatant of the suspension was determined at $514 \mathrm{~m} \mu$ after $20 \mathrm{~min}$.

\section{3) Activity of $\mathrm{SH}$ groups}

After the addition of the denaturing agent, $10 \mathrm{ml}$. of the cell suspension (dry weight $63.6 \mathrm{mg}$.) was left for $10 \mathrm{~min}$., then the cells were washed with distilled water 2 times and suspended in $18 \mathrm{ml}$. of distilled water. One $\mathrm{ml}$. of $8 \mathrm{M}$ ammoniac solution and $1 \mathrm{ml}$. of $2 \mathrm{M}$ $\mathrm{NH}_{4} \mathrm{No}_{3}$ solution were added to this suspension, and the $\mathrm{SH}$ groups contained in the cells were determined by means of amperometric titration with $10^{-3} \mathrm{M} \mathrm{AgNO}$ solution.

\section{4) Fungicidal action of denaturing agents}


Yeast cells (dry weight $10 \mathrm{mg}$.) were suspended in $5 \mathrm{ml}$. of distilled water containing various amounts of denaturing agents, and left for $10 \mathrm{~min}$., then 2 drops of the suspension were inoculated to $5 \mathrm{ml}$. of fresh Peptone-Hayduck medium, and the turbidity of the medium was inspected after 2 days at $30^{\circ} \mathrm{C}$. In the case of acid or alkaline treatment, the cell suspensions were neutralized with dilute $\mathrm{NaOH}$ or $\mathrm{H}_{2} \mathrm{SO}_{4}$ solution and then 2 drops of the suspension were inoculated. In the heating test, the cell suspension was heated in water bath at test temperature for $5 \mathrm{~min}$., and cooled quickly down to room temperature and then 2 drops were inoculated. The fungicidal activity of $\mathrm{HgCl}_{2}$ was also determined after one of the following treatments being carried out.

(1) Cysteine $-\mathrm{HCl} \quad(0 \sim 50 \mathrm{mg}$. in weight) was added to the cell suspension exposed to $\mathrm{HgCl}_{2}$ and then 2 drops of the suspension were inoculated to $5 \mathrm{ml}$. of fresh medium.

(2) The cells exposed to $\mathrm{HgCl}_{2}$ were washed 3 times with water and the cells were suspended in $5 \mathrm{ml}$. of distilled water and then 2 drops were inoculated.

(3) Two drops of the cell suspension exposed to $\mathrm{HgCl}_{2}$ were inoculated to $5 \mathrm{ml}$. of fresh medium containing $0 \sim 5 \mathrm{mg}$. of cysteine-HCl. The results showed that hardly any difference could be found in the fungicidal activity of $\mathrm{HgCl}_{2}$, whether treated with cysteine or with water or without either.

\section{RESULTS AND DISCUSSION}

In these experiments the change of the amount of $\mathrm{Na}$ ion taken in cell has been applied to the indication of the denaturation of yeast cell proteins, which was formerly done by the increase of $\mathrm{SH}$ groups or the change of adsorption of eosine. The denaturation by $\mathrm{HgCl}_{2}$ or formaldehyde was indicated by the change of the amount of $\mathrm{Na}$ ion in cell and of the adsorption of the dye, because the chemicals react to the SH groups contained in the undenatured and denatured yeast cell proteins. The mechanism by which the amount of $\mathrm{Na}$ ion taken in yeast cell is changed remarkably when the cells are exposed to certain chemical or physical treatments is not yet certainly known.

As a result of the comparison between the concentration of denaturing agent to show the fungicidal action and the concentration at which the denaturation of yeast cell proteins was brought about, it was found that the chemicals fell in 2 types. One typical agent was alcohol, the action of which on the yeast cells was similar to that of heating. Alcohol, even below the fungicidal concentration, brought about the denaturation of cell proteins, and the concentration of alcohol 


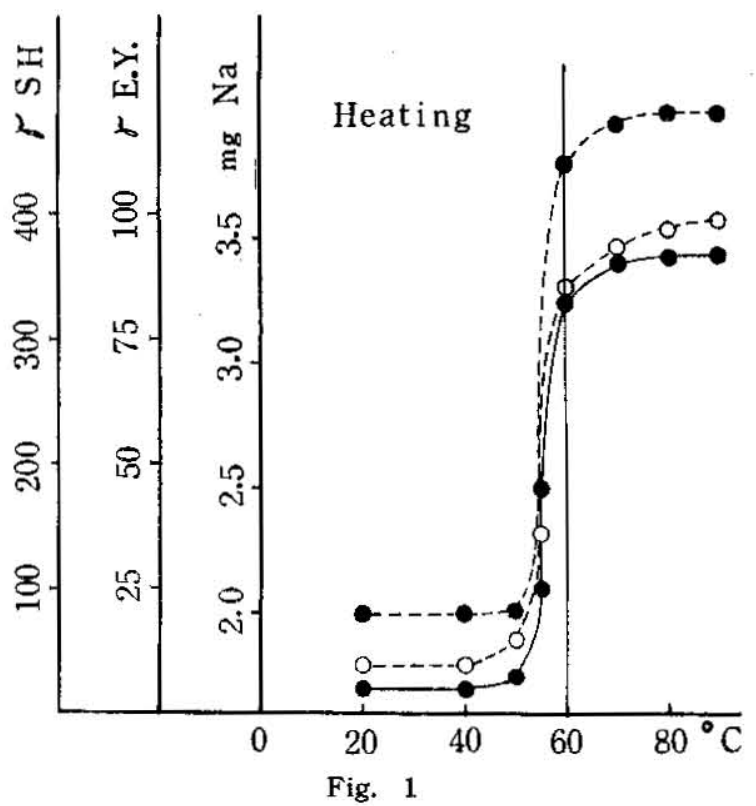

Figs. 1 8. Effects of denaturing agents and heating on the amount of $\mathrm{Na}$ ion in yeast cell, adsorption of eosine by cell and activity of $\mathrm{SH}$ groups of cell protein.

- $-\mathrm{SH}$ group (expressed as $\gamma$ of cysteine) liberated from dry weight $63.6 \mathrm{mg}$. of yeast cells.

O-..-O Eosine Yellowish adsorbed by yeast cell

Dry weight of yeast cell used for

$\begin{array}{llll}\text { Heating } & 54.3 \mathrm{mg} . & \begin{array}{l}\text { Mercuric chloride } \\ \text { Ethanol }\end{array} & 54.3 \mathrm{mg} . \\ \text { Acetone } & & \text { Formaldehyde } & " \\ \text { Phenol } & & \text { Sulfuric acid } & 1.8 \\ & & \text { Potassium hydroxide }\end{array}$

- $\mathrm{Na}$ ion (expressed as $\mathrm{mg}$. of $\mathrm{NaCl} / 100 \mathrm{mg}$. of yeast cells) taken in yeast cell

The longitudinal line in each figure (Heating, $60^{\circ} \mathrm{C}$; Ethanol, $35 \%$; Acetone, $35 \%$; Phenol, 0.2 M; Sulfuric acid, $0.9 \mathrm{M}$; Potassium hydroxide, $0.26 \mathrm{M}$; Mercuric chloride, $0.001 \mathrm{M}$; Formaldehyde $0.5 \mathrm{M}$ ) shows the minimum temperature or concentration to show the fungicidal action. 

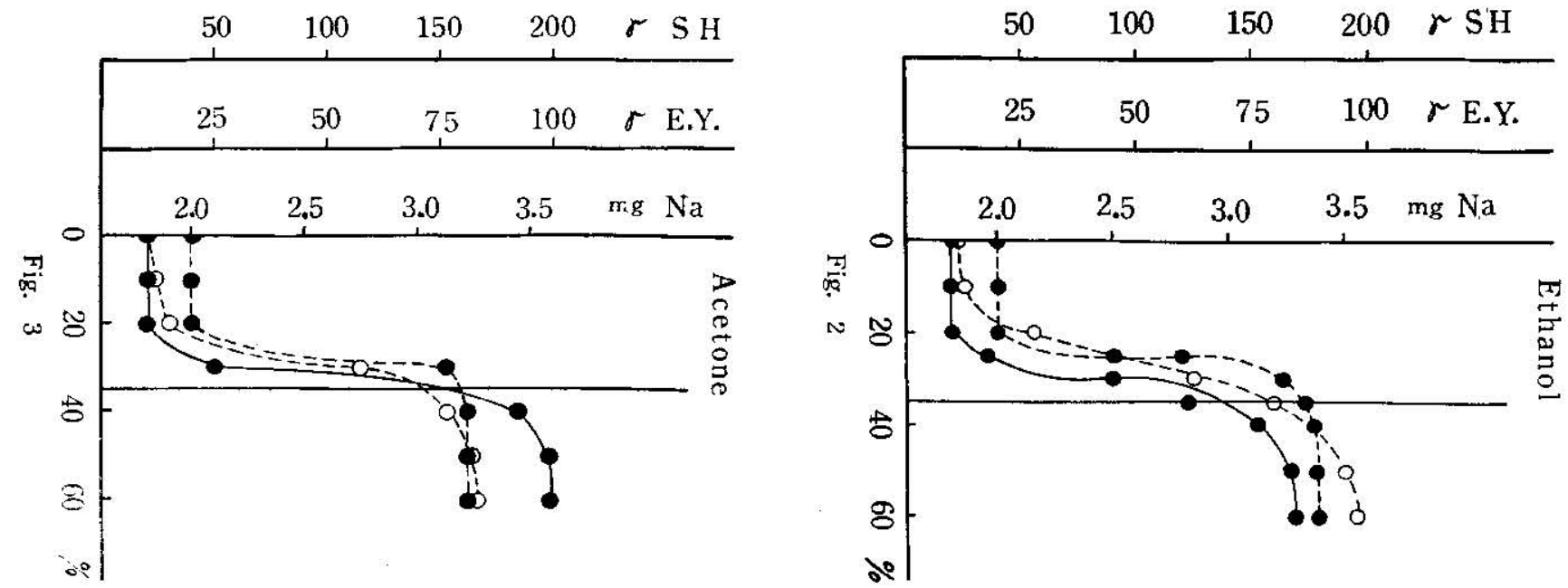


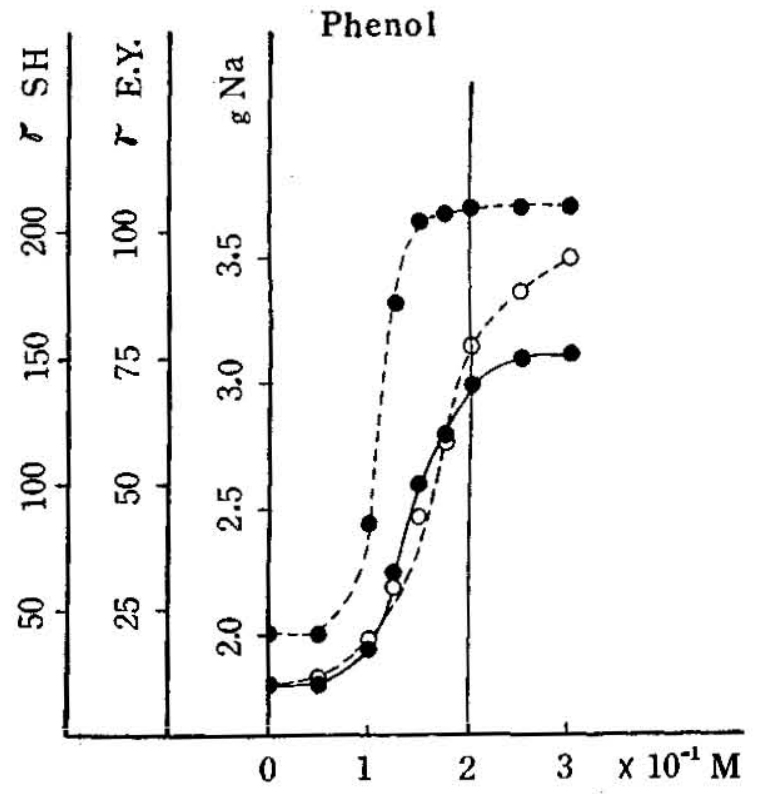

Fig. 4

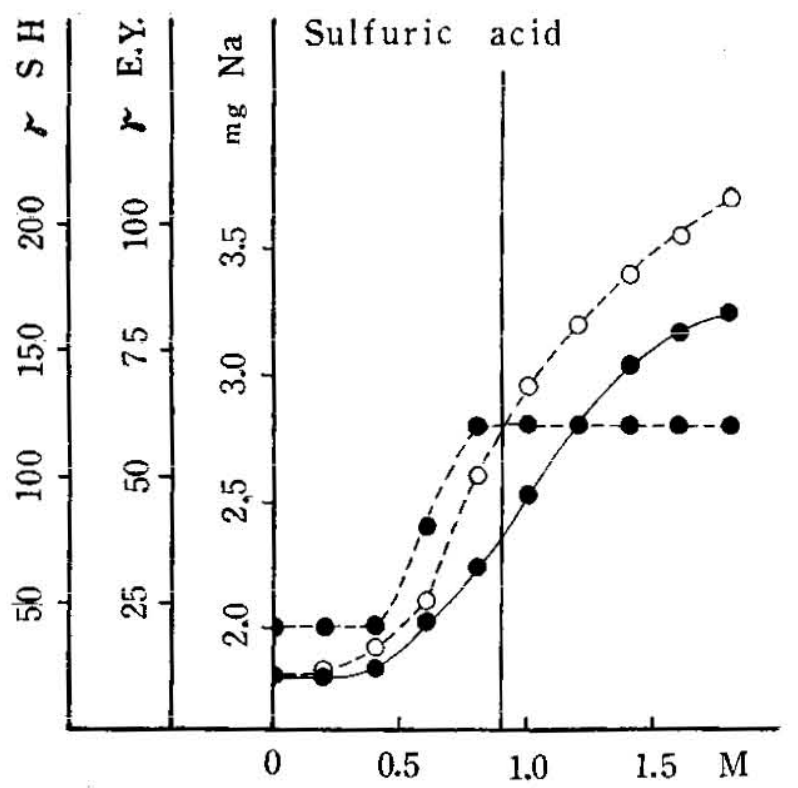

Fig. 5 

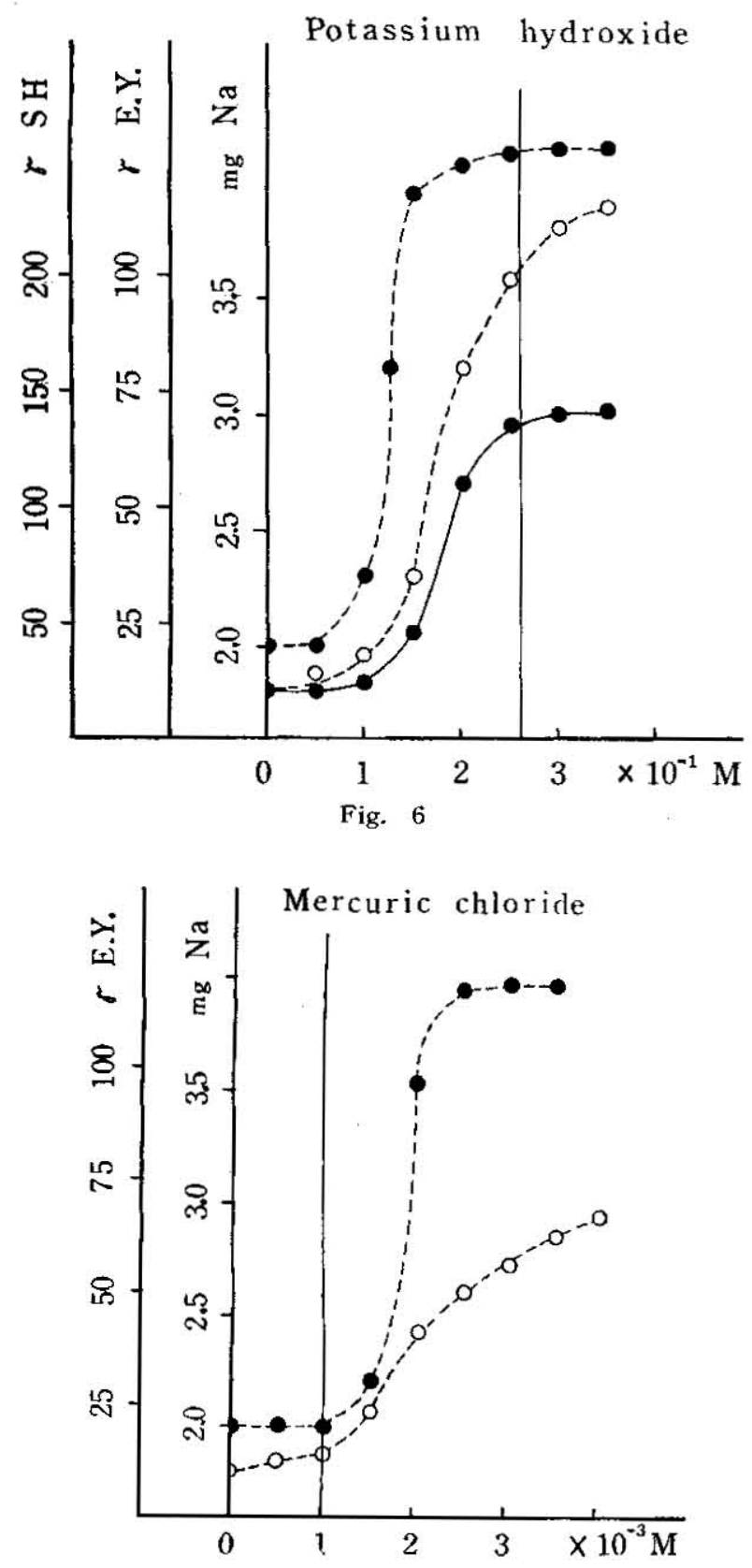

Fig. 7 


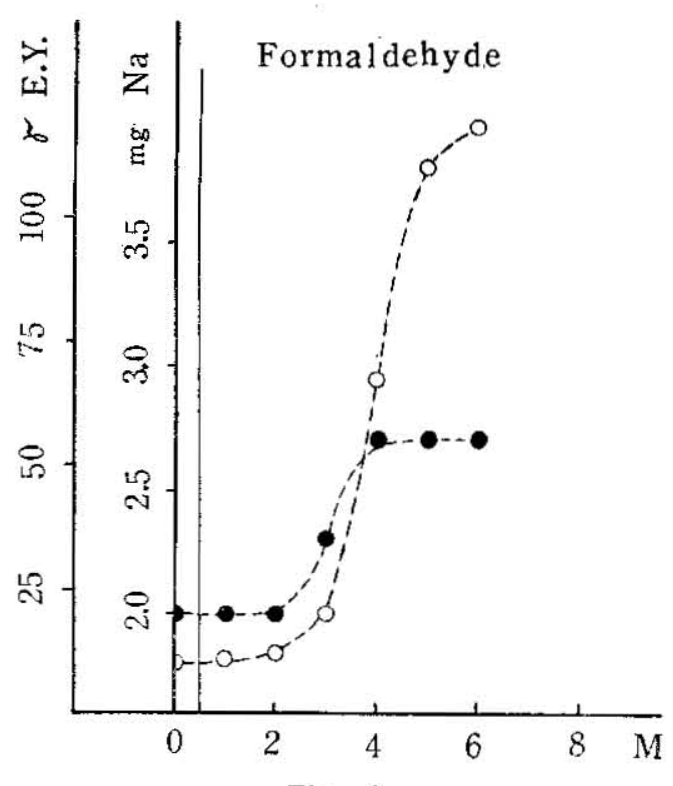

Fig. 8

in which the complete denaturation of the cell proteins arose was almost the same as the fungicidal concentration. Acetone, acid, base and phenol fell within this type. The fungicidal actions of these agents and of heating were due probably to their alterative influence exercised on the fungal cell proteins. There are some theories which contribute to the explanation of the fungicidal action of heating in the wet condition, such as protein denaturation theory, poisoning theory, asphyxiation theory, lipid liberation theory. The author's experimental results may help to give a foundation to the denaturation theory.

$\mathrm{HgCl}_{2}$ and formaldehyde fell in the other type, and showed strong fungicidal action even at the concentration below that which is effective in causing the denaturation of cell proteins. It has been reported that the bacterial cells which have apparently lost their reproductive capability by $\mathrm{Hg}$ ion regain it when the cells have been washed with water or exposed to such sulfhydryl compounds as cysteine or glutathione. It was confirmed by my experiments that, when the $\mathrm{HgCl}_{2}$ treated cells were exposed to the sulfhydryl compounds, the concentration of $\mathrm{HgCl}_{3}$ to show the fungicidal action was also below that which is effective in causing the denaturation of cell proteins. Therefore, it can be reasonably considered that the reaction of $\mathrm{Hg}$ ion to cell proteins is irreversible even at the concentration at which the denaturation of the proteins never arises. 


\section{SUMMARY}

1. The fungicidal action of 7 sorts of denaturing agents and heat treatment were studied concerning their capacity of alternating fungal cell proteins.

2. The alteration of yeast cell proteins was indicated by the change of the amount of $\mathrm{Na}$ ion taken in cells.

3. The comparison between the concentration to show the fungicidal action and the concentration at which the denaturation of the cell proteins arose showed that the denaturing chemicals fell in 2 types.

\section{ACKNOWLEDGMENT}

This investigation was completed at the Chemical Laboratory of Aquatic Products, Faculty of Agriculture, Kyushu University, under the direction of Professor Yukio Tomiyasu. The author wishes to express sincere gratitude for his kind guidance during the course of the investigation.

\section{REFERENCES}

1) Iotchkiss, R. D., 1946. Ann. N. Y. Acad. Sci., 46, 479.

2) Klotz, I. M., 1946. J. Am. Chem. Soc., 63, 2299.

3) Klotz, I. M., Triwush, H. and Walker, F. M., 1948. J. Am. Chem. Soc., 70, 2935.

4) Kusunoki, T., 1952. J. Biochem. (Japan), 39, 245.

5) Haurowitz, F., 1950. "The Chemistry and Biology of Protein," p. 125, Academic Press, New York.

6) Oster, G., 1951. J. chim. phys., 48, 217.

7) Dubos, R. J., 1949. "The Bacterial Cell," p. 287, Harvard. 